\title{
Prinsip Manajemen Kolaborasi Pembinaan Anak Jalanan di Kota Makassar
}

\author{
Dahlan \& Muhammad Darwis \\ Ilmu Administrasi Publik Program Pascasarjana Universitas Negeri Makassar \\ Email: ellanglan@yahoo.co.id
}

\begin{abstract}
ABSTRAK
Manajemen kolaborasi adalah sub konsep manajemen yang berorientasi pada efektivitas dan efisiensi. Dengan dalil tersebut, Johnson, Kast dan Rosenzweig (2002) mengetengahkan pentingnya kolaborasi sebagai jalan keluar dalam implementasi kebijakan program organisasi. Dalam hal ini, meski dalam observasi awal penelitian, tidak ditemukan indikasi manajemen kolaborasi dalam pelaksanaan program pembinaan anak jalanan Kota Makassar, namun penelitian ini diorientasikan untuk merekomendasikan model proses kolaborasi faktual. Menggunakan data analog kualitatif, penelitian ini menghimpun dan menggunakan data yang diperoleh dari Badan Perencanaan Pembangunan Kota Makassar guna menelusuri jejak praktek prinsip manajemen kolaborasi yang dapat dianalogikan sebagai posibilitas penerapan manajemen kolaborasi pada pelaksanaan program pembinaan anak jalanan di Kota Makassar. Penelitian ini mengajukan rekomendasi model proses kolaborasi pelaksanaan program pembinaan anak jalanan Kota Makassar. Suatu rekomendasi yang menunjukkan pelaksanaan prinsip koordinasi, integrasi, simplifikasi, sinkronisasi dan mekanisasi pelaksanaan program pembinaan anak jalanan melalui studi kasus Dinas Sosial dan Dinas Pendidikan Kota Makassar dapat dipraktekkan.
\end{abstract}

Kata Kunci: manajemen, kolaborasi, program pembinaan, anak jalanan

\begin{abstract}
Collaboration management is sub concept of management science, which is oriented to the effectiveness and efficiency. With the argument, Johnson, Kast and Rosenzweig (2002) explore the importance of collaboration as the way out in the implementation of the policy program of the organization. In this case, although in the initial observation study, found no indication of management collaboration in the implementation of development programs of street children, but research is oriented to recommend a factual collaboration process model. Using qualitative analog data, this study collects and uses data obtained from Makassar City Development Planning Board in order to trace the practice of collaborative management principles that can be analogized as a possibility for the implementation of collaborative management at the implementation of development programs of street children in Makassar. This study proposes recommendations for the implementation of the collaborative process model development program of street children Makassar. A recommendation which shows the implementation of the principles of coordination, integration, simplification, synchronization and mechanization for the implementation of the development program of street children through case studies of Social Service and Education Department of Makassar practicable.
\end{abstract}

Keywords: management, collaboration, mentoring, street children 
42 Jurnal Ad'ministrare: Jurnal Pemikiran Ilmiah dan Pendidikan Administrasi Perkantoran, Vol.4, No.1, 2017

\section{PENDAHULUAN}

Keberadaan anak jalanan sudah lazim kelihatan di kota-kota besar di Indonesia. Dari tengah masyarakat pun sudah terdengar berbagai ragam komentar yang mengeluhkan keberadaan anak jalan di ruang-ruang publik. Oleh karena itu, pemerintah dituntut menggunakan instrumen kebijakannya secara optimal guna mengatur dan membina anak jalan, dalam konteks memberikan perlindungan sebab anak merupakan karunia Ilahi dan amanah yang dalam dirinya melekat harkat dan martabat sebagai manusia yang harus dijunjung tinggi. Hak Azasi Anak merupakan bagian dari Hak Azasi Manusia sebagaimana yang tercantum dalam UUD 1945, UU No. 39 tahun 1999 tentang Hak Asasi Manusia, dan Keputusan Presiden Republik Indonesia Nomor 36 tahun 1990 tentang pengesahan Convention on the right of the child (Konvensi tentang Hak-hak Anak).

Sebagai fenomena sosial, masalah anak jalanan tidak serta-merta mendapatkan perhatian dan penanganan melalui instrumen kebijakan pemerintah. Di Indonesia, fenomena anak jalanan sebagai masalah sosial tidak disikapi secara bersamaan oleh pemerintah masing-masing daerah. Selain karena pertumbuhan dan kompleksitas kehidupan sosial masing-masing Kota di Indonesia memang berbeda, hal ini terkait juga dengan peran pemerintah kota sebagai instrumen manajemen dalam pembangunan kota. Sebagai instrumen manajemen pembangunan yang berbasis teknokratik dan politik, pemerintah kota dapat saja menunda untuk membina dan menangani permasalahan anak jalanan. Hal itu tercermin melalui kebijakan pembangunan (RKPD) pemerintah kota setiap tahunnya. Bahkan dengan mengacu pada konsepsi kebijakan Dye (1978), pemerintah kota dapat saja memutuskan untuk tidak mengambil tindakan apa-apa terkait anak jalanan, baik sebagai fenomena sosial maupun sebagai masalah publik.

Keputusan pemerintah untuk mengambil tindakan atau langkah-langkah pembinaan dan penanganan terhadap fenomena anak jalanan di Indonesia baru dimulai pada dekade 1970an. Hal itu diinisiasi oleh Pemerintah Kota Daerah Khusus Ibukota Jakarta pada masa arus urbanisasi besar-besaran melanda Jakarta sebagai Ibu Kota Negara. Pemerintah Kota Makassar sendiri baru mulai mengalokasikan sumberdaya publiknya dalam bentuk kebijakan yang tertuju pada fenomena atau komunitas anak jalanan pada dekade berikutnya, yakni 1980an.

Tercatat, kebijakan program kegiatan pertama yang ditempuh oleh Pemerintah Kota Makassar dalam merespon permasalahan anak jalanan kota, tertuang dalam Hasil Rapat Kerja Pemerintah Kota Makassar Tahun 1985. Pada era tersebut, diksi yang digunakan untuk mengidentifikasi fenomena anak jalanan dalam kebijakan program Pemerintah Kota Makassar adalah Program Pembinaan Anak Gelandangan. Kemudian secara inkremental, kebijakan program pembinaan anak jalan tersebut kembali hadir dalam tahun-tahun berikutnya hingga era Millenium ini dengan tag line program kebijakan 'pembinaan anak jalanan'.

Dengan demikian, dapat dikatakan bahwa upaya pembinaan terhadap anak jalanan bukannya tidak pernah dilakukan. Pemerintah Kota Makassar senantiasa memperbaharui kebijakan program kegiatannya mengikuti kecenderungan situasi masyarakat dan perkembangan ilmu manajemen program. Salah satu variasi terkini dari kebijakan program kegiatan Pemerintah Kota Makasar yang dilaksanakan sejak tahun 1998 adalah pencanangan Program Rumah Singgah, dimana bagi anak jalanan disediakan rumah penampungan dan pendidikan (Draf Pembinaan Anak Jalanan Pemkot Makassar, 1998). Selain itu, pemerintah melalui Dinas 
Pendidikan Kota Makassar, menyelenggarakan program bersama sejumlah LSM yang concern terhadap masalah ini. Kebanyakan bergerak dalam bidang pendidikan alternatif bagi anak jalanan.

Tampak jelas bahwa kebijakan program yang ditujukan sebagai bentuk penanganan masalah anak jalanan sudah diupayakan, baik melalui instansi teknis yang langsung bertindak selaku leading sector masalah sosial ini. Kerjasama instansi teknis dalam jaringan pemerintah kota dengan berbagai unsur masyarakat sipil juga sudah berlangsung. Dengan demikian, tentu hal tersebut mengindikasikan suatu dinamika interaktif antar organisasional. Dinamika interaktif antar organisasional ini berlangsung dalam jaringan kerja pemerintah kota, berlangsung pula antar pemerintah dengan aktor pembangunan lain sebagaimana konsepsi good governance.

Namun paradigma penelitian ini tidak hendak menjejakkan diri pada konstelasi bagaimana keseluruhan interaksi antar organisasional tersebut berlangsung secara demokratis menurut konsepsi good governance, melainkan menitikberatkan pandangannya pada hubungan administrative manajerial antar penyelenggaraan program pembinaan anak jalanan dalam jaringan Pemerintah Kota Makassar. Dalam hal ini, konteks implementasi program kegiatan masing-masing institusi teknis dalam jaringan Pemerintah Kota Makassar melalui penerapan prinsip-prinsip manajemen kolaborasi yakni Koordinasi, integrasi, simplifikasi, sinkronisasi dan mekanisasi (Johnson, Kast \& Rosenweig, 2002; 11). Urgensi dan relevansi pelaksanaan fungsifungsi manajemen kolaborasi tersebut memungkinkan penyelenggaraan program pembinaan anak jalan, mencapai efisiensi dan efektivitas implementasi yang tinggi mengingat kemanfaatan prinsip-prinsip manajemen kolaborasi.

Kemanfaatan penerapan prinsip manajemen kolaborasi tersebut memungkinkan kerja para aktor dalam pelaksanaan program kegiatan pembinaan anak jalanan dimaksud mencapai value dan manfaat; 1) integrasi kegiatan dan tujuannya; 2) kesesuaian perspektif akibat perbedaan nomenklatur 3) keselarasan dan harmonisasi waktu, data serta aspek teknis kegiatan; 4) saling support perangkat berteknologi dalam pelaksanaan kegiatannya. Namun keseluruhan value dan manfaat tersebut hanya dapat diwujudkan melalui pelaksanaan koordinasi antar instansial (lintas sektoral) dalam jaringan Pemerintah Kota Makassar yang memiliki relevansi program kegiatan satu sama lain.

Dalam berbagai dokumen, termasuk keterangan kepala SKPD hingga pernyataan Kepala Pemerintahan Kota Makassar, semua familiar dengan penggunaan istilah koordinasi lintas sektoral sebagai indikasi diterapkannya manajemen kolaborasi lintas manajemen SKPD. Namun khusus dalam kaitan interaksi lintas manajemen antara Dinas Sosial dengan Dinas Pendidikan Kota Makassar, tidak ditemukan bukti-bukti penerapan prinsip-prinsip manajemen kolaborasi. Bahkan, kedua pihak dinas tersebut tidak saling mengetahui program masing-masing yang terkait karena mengacu pada satu fenomena sosial yang sama yakni anak jalanan. Data yang menunjukkan bukti-bukti dilakukannya koordinasi oleh Dinas Sosial Kota Makassar satusatunya hanyalah pertemuan dengan pihak Yayasan Peduli Negeri, sebuah lembaga partisipasi pembangunan yang aktif terlibat melalui program pembinaan anak jalanan Dinas Sosial Kota Makassar. Tidak ada bukti koordinasi antar leadingsectors, terutama leading sectors yang menangani fenomena sosial yang sama dengan Dinas Sosial.

Kelemahan praktek manajemen kolaborasi yang menyebabkan masih terjadinya perbedaan data anak jalanan antara Dinas Sosial dan Dinas Pendidikan disebabkan oleh 
ketiadaan penerapan prinsip sinkronisasi. Dalam hal ini sinkronisasi adalah salah satu fungsi teknis dalam manajemen kolaborasi yang dapat menghindarkan kedua institusi teknis di jajaran pemerintah Kota Makassar dari pemilikan data yang debatable.

Penanganan masalah anak jalanan sesungguhnya bukan saja menjadi tanggung jawab salah satu pihak saja (Dinas Sosial), tetapi merupakan tanggung jawab bersama antar jaringan pemerintah, LSM, akademisi dan masyarakat, secara keseluruhan. Peran dan fungsi organisasi pemerintah Kota Makassar sebagai institusi publik seharusnya meliput masalah anak jalanan sebagai persoalan dalam aspek kehidupan sosial kemasyarakatan. Persoalannya, selama ini, aksi-aksi penanganan anak jalanan masih dilakukan secara sporadik, sektoral dan temporal serta kurang terencana, kurang terintegrasi secara baik dalam suatu fungsi manajerial yang bersifat kolaboratif. Hal tersebut menjadi bukti bahwa masyarakat dan Pemerintah Kota Makassar tidak terbiasa berkolaborasi, bahkan terhadap sesama institusi dalam jaringan kerja organisasi publik dalam lingkup Pemerintah Kota Makassar sendiri sekalipun. Akibatnya, efisiensi dan efektivitas program dalam fakta penanganan menjadi tidak menemukan akurasi dan fenomena anak jalanan tetap saja eksis hingga kini. Kompleksitas tersebut kemudian menyiratkan inefisiensi dan inefektifitas, yang semestinya diacu sebagai target dan tujuan praktek manajemen publik.

Disamping performa yang timbul sebagai efek manajerial tersebut, dimungkinkan pula dampak finansial yakni efektivitas dan efisiensi penggunaan anggaran daerah. Sebagaimana historisitas yang diuraikan terdahulu, dapat tergambarkan akumulasi penggunaan anggaran pembiayaan program ini dan rasionalitasnya. Apabila argumentasi ini difokuskan pada Dinas Sosial dan Dinas Pendidikan melalui program kegiatan pembinaan anak jalanannya yang relavan satu sama lain, maka akumulasi penggunaan anggaran berikut dapat menunjukkan dampak finansial dari pelaksanaan program tersebut.

Data faktual menunjukkan, Dinas Sosial memiliki 5 (lima) ragam program kegiatan yang secara spesifik fokus pada komunitas anak jalanan. Dinas Pendidikan memiliki 3 (tiga) ragam program kegiatan dalam satu tahun RKPD Pemerintah Kota Makassar. Rata-rata penganggaran tertinggi satu program kegiatan tersebut berkisar \pm Rp. 200 Juta. Berarti satu tahun RKPD menghabiskan anggaran sebesar Rp. 1,6 Miliar. Bila program yang sama dilaksanakan melalui 5 kali RKPD tahunan, maka pemborosan anggaran menjadi Rp. 8 Miliar. Padahal program pembinaan anak jalanan Kota Makassar terbukti tidak manjur karena fenomena anjal tetap eksis hingga kini.

Situasi faktual tersebut, dalam penelitian ini dikukuhkan secara determinatif bahwa kedua instisuti teknis dalam studi kasus ini tidak menerapkan kelima prinsip manajemen kolaborasi dalam pelaksanaan program pembinaan anak jalanan di Kota Makassar. Determinasi ini akan mengarahkan bentuk rumusan masalah penelitian selanjutnya. Demikian ekstrimnya nilai dari pendekatan terhadap fenomena anak jalan di Kota Makassar tersebut sehingga dari sekian banyak aspek yang mungkin mempengaruhi ketidak-efektifan dan ketidak-efisienan pelaksanaan program pembinaan anak jalanan, maka berdasarkan faktual problem penelitian tersebut, kemudian ditetapkan determinan manajemen kolaborasi sebagai aspek teoritis yang urgen dan relevan untuk menuntun arah penelitian. Dimensi manajemen kolaborasi ini ditetapkan sebagai entry point untuk masuk dan meneliti kolaborasi kebijakan program 
kegiatan pembinaan anak jalanan Kota Makassar sebagai possibility tersisa sebelum indikasi malmanagemen benar-benar dapat menjadi klaim dalam hal ini.

Sekaitan dengan latar belakang masalah dan faktual problem tersebut, rumusan masalah diajukan sebagai berikut: (1) Mengapa pelaksanaan program pembinaan anak jalanan di Kota Makassar tidak dapat optimal berlandas pada prinsip koordinasi, integrasi, simplifikasi, sinkronisasi dan mekanisasi?

\section{METODE PENELITIAN}

Jenis penelitian yang digunakan dalam penelitian ini, yaitu menggunakan penelitian kualitatif, sedangkan pendekatan yang digunakan adalah pengumpulan data dilakukan melalui teknik wawancara untuk memperoleh data primer. Data sekunder dihimpun melalui teknik observasi dan telaah dokumen. Sumber data berasal dari informan berikut; Kepala Dinas Sosial, Kepala Dinas Pendidikan, Sekretaris Dinas Sosial, Sekretaris Dinas Pendidikan, Kepala Sub Bidang Rehabilitasi Sosial Dinas Sosial, Kepala Sub Bidang Pendidikan Masyarakat Dinas Pendidikan, lima orang pelaksana kegiatan pembinaan anak jalanan Dinas Sosial dan lima orang pelaksana kegiatan pembinaan anak jalanan Dinas Pendidikan Kota Makassar. Dalam perkembangan proses pengumpulan data, kondisi faktual yang membuktikan bahwa tidak terdapat praktek prinsip-prinsip manajemen kolaborasi dalam pelaksanaan program pembinaan anak jalanan antar kedua instansi dimaksud. Penelitian kemudian memutuskan untuk menggunakan data analog (dari fenomena lain) yakni fakta praktek prinsip-prinsip manajemen kolaborasi pada salah satu simpul dalam tahap perencanaan program kerja SKPD bidang sosial budaya. Data yang diperoleh melalui informan Kepala Bidang Sosial Budaya Bappeda, secara signifikan bersifat analog dengan kebutuhan data dimaksud.

\section{HASIL PENELITIAN PEMBAHASAN}

Sebab Musabab Pelaksanaan program pembinaan anak jalanan di Kota Makassar tidak dapat optimal berlandas pada fungsi-fungsi teknis manajemen kolaboratif

Urgensi dan relevansi fungsi-fungsi manajemen kolaborasi kerja dalam rangka optimalisasi pelaksanaan program kegiatan pembinaan anak jalanan sejurus dengan penjelasan perspektif proses dalam ilmu manajemen. Bahwa prinsip koordinasi, integrasi, simplifikasi, sinkronisasi dan mekanisasi adalah fungsi manajemen yang dijalankan melalui peran komunikasi antar personil dalam divisi dan atau unit-unit organisasi dalam suatu jaringan. Hal tersebut memberikan gambaran tentang apa yang sekiranya dilakukan oleh seorang pelaksana manajemen ketika menjalankan tugasnya (Mintzberg dan Quinn, 1996).

Tuntutan tersebut sebangun dengan tugas para pelaksana program kegiatan pembinaan anak jalanan pada kedua institusi teknis, Dinas Sosial dan Dinas Pendidikan Kota Makassar. Baik melalui peran manajer lini tengah, dalam hal ini Kepala Bidang dan atau Kepala Sub Bidang pada kedua institusi teknis tersebut, terlibat dalam proses komunikasi intens dalam pertemuan multi stakeholders pembangunan sosial budaya yang difasilitasi oleh Bidang Sosial 
Budaya Badan Perencanaan Pembangunan Daerah (Bappeda) Kota Makassar. Meskipun momentum ini merupakan tahapan perencanaan, namun tampak jelas bahwa, baik secara regulative mengacu pada Permendagri Nomor 13 Tahun 2006 Tentang Pedoman Pengelolaan Keuangan Daerah maupun secara manajerial, diperlukan dan dibutuhkan upaya manajerial yakni menjalankan komunikasi prinsip-prinsip manajemen kolaborasi.

Analisa terhadap data yang dihimpun menunjukkan bahwa tidak satupun personil yang terlibat dalam pertemuan multi stakeholders pembangunan sosial budaya Kota Makassar menyadari dan mengetahui bahwa mereka telah memerankan dan mengkomunikasikan prinsipprinsip manajemen kolaborasi pada tahap perencanaan. Hal ini tentunya menjadi determinan penentu bagi praktek manajemen kolaborasi lanjutan yakni pada tahap pelaksanaan program pembangunan melalui kategori kegiatan sosial budaya yang dimiliki oleh masing-masing leading sectors. Oleh karena ketidaktahuan tersebut, maka secara kontinyu terbukti tidak ada kelanjutan dimana para aktor mengetahui dan memahami bahwa ada kebutuhan komunikasi prinsip-prinsip kolaborasi pada tahap pelaksanaan program kegiatan. Meskipun demikian adanya, namun data faktual menunjukkan bahwa proses pelaksanaan program kegiatan pembinaan anak jalanan yang dilakukan oleh Dinas Sosial Kota Makassar dapat secara estafet direkomendasikan kepada Sub Bidang Pendidikan Masyarakat Dinas Pendidikan Kota Makassar. Dinas Pendidikan, dalam hal ini, pula meresponnya dengan mengakomodir sejumlah anak jalanan yang masuk kategori usia didik/sekolah untuk diteruskan pembinaannya dalam program kegiatan pendidikan masyarakat.

Konstelasi tersebut sesungguhnya dapat dielaborasi oleh kedua SKPD (dinas Sosial dan Dinas Pendidikan Kota Makassar) melalui pelaksanaan prinsip-prinsip manajemen kolaborasi tahap pelaksanaan program kegiatan guna pencapaian efektivitas dan efisiensi pelaksanaan yang lebih baik. Hal tersebut tampak dalam tabel analisis temuan penelitian sebagai berikut;

Tabel 1

Hasil Analisa Praktek Komunikasi yang Mengindikasikan Upaya Koordinasi pada Pertemuan Multi Stakeholders Pembangunan Sosial Budaya Bappeda Kota Makassar

\begin{tabular}{|c|c|c|}
\hline Kondisi Ideal & Temuan & Sintesa \\
\hline $\begin{array}{l}\text { Koordinasi } \\
\text { harus terpusat, } \\
\text { sehingga ada } \\
\text { unsur } \\
\text { pengendalian } \\
\text { guna } \\
\text { menghindari } \\
\text { tiap bagian } \\
\text { bergerak } \\
\text { sendiri-sendiri } \\
\text { yang } \\
\text { merupakan } \\
\text { kodrat yang } \\
\text { telah ada dalam }\end{array}$ & $\begin{array}{l}8 \text { SKPD yang masuk } \\
\text { dalam kategori } \\
\text { stakeholders } \\
\text { pembangunan sosial } \\
\text { budaya melakukan } \\
\text { rapat koordinasi di } \\
\text { Bappeda Kota } \\
\text { Makassar. Rapat ini } \\
\text { merupakan tahapan } \\
\text { perencanaan program } \\
\text { kegiatan. Dalam hal } \\
\text { ini, Bidang Sosial } \\
\text { Budaya Bappeda } \\
\text { bertindak selaku }\end{array}$ & $\begin{array}{l}\text { - Peranan Bidang Sosial Budaya Bappeda Kota } \\
\text { Makassar dalam pertemuan (rapat) tersebut } \\
\text { sudah mengindikasikan komponen koordinasi } \\
\text { yakni pelibatan melalui pemusatan dimana } \\
\text { dapat dicapai keterpaduan pekerjaan. Aspek } \\
\text { nilai juga tercapai yakni menunjukkan keadaan } \\
\text { yang saling mengisi dan memberi. } \\
\text { - Pendekatannya sudah multi instansional, } \\
\text { dengan wujud saling memberikan informasi } \\
\text { yang relevan untuk menghindarkan saling } \\
\text { tumpang tindih tugas yang satu dengan tugas } \\
\text { yang lain. } \\
\text { - Kelemahannya terletak pada kesinambungan } \\
\text { koordinasi. Rangkaian kegiatan yang sama }\end{array}$ \\
\hline
\end{tabular}




\begin{tabular}{|c|c|c|}
\hline Kondisi Ideal & Temuan & Sintesa \\
\hline 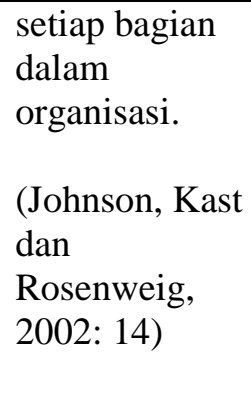 & $\begin{array}{l}\text { fasilitator. Arah dan } \\
\text { pola pembicaraan } \\
\text { terkait penganggaran } \\
\text { program kegiatan } \\
\text { kedelapan SKPD } \\
\text { tersebut dan } \\
\text { mencakup analisis } \\
\text { terhadap kesesuaian } \\
\text { nomenklatur. }\end{array}$ & $\begin{array}{l}\text { hanya dilakukan sekali setahun terkait } \\
\text { penyusunan RKPD. Penerapan prinsip } \\
\text { manajemen koordinasi, dalam hal ini hanya } \\
\text { berlangsung pada tahap perencanaan program } \\
\text { kegiatan. Tidak ada indikasi upaya yang sama } \\
\text { dan saling menyambung sebagai usaha yang } \\
\text { menegaskan adanya keterkaitan dengan } \\
\text { kegiatan sebelumnya (kolaborasi perencanaan } \\
\text { dan kolaborasi pelaksanaan). }\end{array}$ \\
\hline
\end{tabular}

Sumber: Diolah dari data primer, 2016

Materi tampilan tabel 1 tersebut dalam terminology Johnson, Kast dan Rosenweig (2002: 14) disebut sebagai A manager skills. Dalam rinciannya, terminology tersebut dapat dimaknai bahwa peran koordinasi, sesungguhnya adalah keterampilan seorang manajer. Dalam konteks penelitian ini, peranan tersebut dijalankan dengan baik oleh Bidang Sosial Budaya Bappeda Kota Makassar dalam momentum rapat koordinasi yang dinamai pertemuan multi stakeholders pembangunan sosial budaya Kota Makassar.

Dengan demikian, analisa terkait prinsip kolaborasi ini, meskipun tahapannya dilaksanakan dalam tahapan perencanaan program secara teknokratik, akan tetapi dapat membuktikan bahwa peranan Bidang Sosial Budaya Bappeda Kota Makassar dalam pertemuan (rapat) tersebut sudah mengindikasikan pelaksanaan komponen, yakni koordinasi melalui upaya pelibatan, pemusatan dimana dapat dicapai keterpaduan pekerjaan. Penelitian Khatmah Ahmad (2015) yang menyoroti peluang kolaborasi sosial berbasis aktor good governance, juga menyinggung peranan Badan Perencanaan Pembangunan Daerah (Bappeda) dalam mengarahkan proses kolaborasi manajerial (teknokratik). Kolaborasi manajerial dimaksud dalam tesis tersebut, mengakui bahwa sejauh ini, kolaborasi perencanaan hanya terfokus pada proses perencanaan teknokratik, yang dimulai dari tahapan musyawarah pembangunan tingkat dasar (dusun-desa-kelurahan), yang kemudian dikolaborasikan secara manajerial kembali pada pertemuan multi stakeholder melalui fasilitasi bidang-bidang relevan di Badan Perencanaan Pembangunan Daerah (Bappeda).

Data faktual memang menunjukkan bukti dilaksanakannya prinsip koordinasi dan hal itulah pula yang berpeluang mengarahkan sikap pemenerimaan Dinas Pendidikan Kota Makassar sehingga membuka diri dan menerima transfer anak jalanan usia didik/sekolah dari Dinas Sosial guna mendapatkan pembinaan melalui kegiatan pendidikan masyarakatnya. Namun perlu digarisbawahi bahwa peran positif Dinas Pendidikan terhadap hasil pelaksanaan kegiatan patrolii anak jalanan Dinas Sosial Kota Makassar itu tidak memenuhi syarat untuk dikatakan bahwa program kegiatan pendidikan masyarakat Dinas Pendidikan adalah program support bagian program pembinaan/patrolii anak jalanan Dinas Sosial.

Terkait praktek prinsip koordinasi dalam operasi manajemen kolaborasi, Johnson, Kast dan Rosenweig (2002) memang tidak merinci bahwa koordinasi kolaboratif harus diselenggarakan dalam konteks perencanaan atau konteks pelaksanaan program kegiatan dan atau justru kedua konteks tersebut. Selain itu, tesis pemikirannya juga tidak mengkategorisasi 
kedudukan masing-masing prinsip, apakah seluruh prinsip itu setara atau justru sebagian prinsip justru merupakan akibat dari penerapan salah sau prinsip yang ada. Oleh karena itu, penelitian ini berpeluang mengajukan penataan terhadap konsepsi tersebut.

Selain pembuktian sebagai komponen inti manajemen kolaborasi, prinsip koordinasi juga bermuatan nilai (benefit) dari pelaksanaannya. Aspek nilai yang dimaksudkan dalam pelaksanaan koordinasi adalah diwujudkannya keadaan yang saling mengisi dan memberi. Pendekatannya, pula sudah multi instansional, dengan wujud saling memberikan informasi yang relevan untuk menghindarkan saling tumpang tindih antara program kegiatan SKPD yang bertindak selaku leading sectors pembangunan sosial budaya satu sama lainnya. Pada tataran inilah, apabila koordinasi tersebut dijalankan melalui pengkomunikasian agenda yang ada, maka kekhasan dan kecenderungan program kegiatan Dinas Sosial dan Dinas Pendidikan dapat menemukan titik aksesnya sebagai suatu upaya kolaborasi kegiatan.

Kelemahannya menurut perspektif penelitian ini terletak pada kesinambungan koordinasi. Rangkaian kegiatan yang sama hanya dilakukan sekali setahun terkait penyusunan RKPD. Tidak ada indikasi upaya yang sama dan saling menyambung sebagai usaha yang menegaskan adanya keterkaitan dengan kegiatan sebelumnya yakni kolaborasi perencanaan kentinyu ke kolaborasi pelaksanaan. Kontinyuitas koordinasi tersebut akan mengubah peranan SKPD terkait menjadi koordinator sebagai kelanjutan daripada koordinasi perencanaan tadi mengingat besarnya dan niscayanya potensi hubungan saling pintas-memintas antar satu program kegiatan SKPD dengan SKPD lainnya pada tahap pelaksanaan. Sebagaimana focus studi ini, proses pemusatan (koordinasi) hendak diidentifikasi melalui peranan Dinas Sosial dalam membaca, menindaklanjuti dan mengelola potensi saling pintas-memintas antar antara program Dinas Sosial dengan program kegiatan Dinas Pendidikan yang niscaya adanya sebagaimana diakui dalam koordinasi perencanaan tersebut melalui pembahasan (komunikasi rapat) selisih perspektip yang diakibatkan oleh perbedaan nomenklatur masing-masing SKPD.

Dengan demikian, kondisi dimaksud tersebut, memindahkan kendali peran koordinasi (selaku coordinator) dari pihak Bidang Sosial Budaya Bappeda Kota Makassar kepada Dinas Sosial atau kepada SKPD lain yang memiliki keterkaitan program kegiatan yang lebih besar/menonjol dalam suatu entitas sasaran kegiatan dimana program kegiatan SKPD lain juga terkait secara relative. Hal ini sangat mungkin untuk dilakukan dengan berdasar kepada notulensi rapat/pertemuan multi stakeholders pembangunan sosial budaya yang digelar dalam rangka tahapan perencanaan tersebut. Hanya saja tidak ditindaklanjuti kemudian oleh aktoraktor SKPD relevan sebagaimana dimaksudkan.

Secara implisit konten dari pada rekomendasi notulensi rapat/pertemuan multi stakeholders pembangunan sosial budaya tersebut sesungguhnya bermakna rekomendasi ke arah koordinasi lanjutan yakni tahap pelaksanaan program kegiatan. Hal itu tampak dalam jejak notulensi kolaborasi perencanaan tersebut. Jejak notulensi dimaksud memuat aspek-aspek terkait program kegiatan SKPD satu sama lain, baik menurut perspektif nomenklaturnya masing-masing maupun berdasarkan aspek-aspek teknis daripada program kegiatan relevan yang memiliki possibility untuk dikomunikasikan kembali secara kolaboratif pada tahap pelaksanaannya. Jika dikontekstualisasikan kepada pelaksanaan prinsip-prinsip kolaborasi, maka hal inilah yang sejatinya berperan mengarahkan momentum pertemuan multi stakeholders lanjutan yakni tahap pelaksanaan program kegiatan dengan agenda yang tentu lebih bersifat 
teknis mengatur peran SKPD terkait, dalam pelaksanaan program kegiatan pembinaan anak jalanan di Kota Makassar. Dalam momentum itu, Dinas Sosial menduduki peran pengendali (koordinasi) atas Dinas Pendidikan dalam pelaksanaan program kegiatan pembinaan anak jalanan. Termasuk dalam hal ini, apabila posisi SKPD lain, seperti Dinas Tenaga Kerja Kota Makassar dibahas keikutsertaannya dalam kolaborasi pelaksanaan kegiatan pembinaan anak jalanan.

Intensi ini tentu terkait dengan keperluan dan kebutuhan komunikasi pada tahap pelaksanaan program kegiatan pembinaan anak jalanan pasca penetapan program kegiatan melalui Peraturan Daerah. Hal ini menjadi niscaya sebab, proses yang mesti dilalui oleh rencana program kegiatan selanjutnya adalah pembahasan pada tingkat legislative dimana sangat lazim terjadi, rancangan yang telah dibakukan sebagai rencana mengalami perubahan dan atau pergeseran. Meski hal tersebut disebabkan oleh faktor non manajerial yakni persoalan anggaran, namun justru anggaranlah yang menjadi sukma program kegiatan yang akan dilaksanakan kemudian dalam kolaborasi kerja antar leading sectors pembangunan.

Selanjutnya, dalam momentum pertemuan itu juga dihimpun data bahwa prinsip integrasi berlangsung pula dalam komunikasi multi stakeholders tersebut. Meski Johnson, Kast dan Rosenweig (2002) tidak mengidentifikasi dan mengurai prinsip ini sebagai core benefit dari upaya koordinasi, akan tetapi penelitian ini menilai integrasi sebagai salah satu prinsip pokok dalam manajemen kolaborasi , tidak sebangun dengan prinsip koordinasi. Menurut data faktual penelitian ini, integrasi dalam konteks ini merupakan linier effect dari praktek koordinasi yang diselenggarakan.

Prinsip integrasi manajemen kolaborasi pelaksanaan program kegiatan pembinaan anak jalanan menurut data faktual penelitian ini, berdasarkan sifat, ciri dan dimensinya, sesungguhnya tidak dapat mandiri sebagai sebuah tindakan terpisah dari peran komunikasi yang dilakoni oleh para wakil SKPD yang hadir dalam pertemuan tersebut. Ia merupakan kontinyuitas dari peran komunikasi koordinasi yang diselenggarakan. Bahkan termasuk pula kontunyuitas daripada peran komunikasi prinsip manajemen kolaborasi lainnya seperti simplifikasi dan sinkronisasi. Ketiga prinsip tersebut, dalam konteks ini menjadi unsur pembangun integrasi yang diproyeksikan oleh manajemen kolaborasi yakni akan mengefisienkan dan mengefektifkan pelaksanaan program kegiatan pembinaan anak jalanan Kota Makassar. Konstalasi ini, mengarahkan penilaian kita bahwa praktek komunikasi prinsipprinsip manajemen kolaborasi akan secara tegas memproyeksikan efisiensi dan efektivitas apabila dipraktekkan pada tahapan pelaksanaan program kegiatan.

Argumentasi hipotetik mayor yang diperoleh melalui analisa data faktual praktek prinsip koordinasi adalah sebagai berikut: "Praktek prinsip koordinasi yang terselenggara dalam tahap kolaborasi perencanaan program pembangunan sosial budaya Kota Makassar niscaya mengarahkan dan mewujudkan prinsip integrasi, yang sekaligus mewujudkan prinsip integrasi, simplifikasi dan sinkronisasi melalui proses komunikasi yang berlangsung."

Argumentasi hipotetik minor yang diperoleh melalui analisa data faktual praktek prinsip koordinasi adalah sebagai berikut: "Perwujudan prinsip koordinasi dalam praktek manajemen kolaborasi demikian itu mengekspos kedudukannya sebagai komponen inti (core component) dan kedudukan prinsip integrasi, simplifikasi dan sinkronisasi sebagai komponen nilai (core value) Manajemen Kolaborasi Pembangunan Sosial Budaya Kota Makassar.” 
Tabel 2

Hasil Analisa Praktek Komunikasi yang Mengindikasikan Upaya Integrasi pada Pertemuan Multi Stakeholders Pembangunan Sosial Budaya Bappeda Kota Makassar

\begin{tabular}{|l|l|l|}
\hline \multicolumn{1}{|c|}{ Kondisi Ideal } & \multicolumn{1}{|c|}{ Temuan } & \multicolumn{1}{c|}{ Sintesa } \\
\hline Integrasi & Personil peserta & Perwujudan prinsip integrasi dalam mekanisme \\
merupakan proses & rapat koordinasi & koordinasi berciri konten komunikasi. Oleh \\
penyesuaian antar & leding sectors & karena itu, perwujudan prinsip ini cenderung \\
institusi yang & pembangunan & tidak disadari oleh personil yang mengikuti \\
saling berbeda & sosial tidak & rapat koordinasi. Melalui rapat koordinasi \\
sehingga & menyadari/mengeta & tersebut unsur pembangun prinsip integrasi \\
menghasilkan & hui teknis, tujuan & terpenuhi dengan hadirnya 8 SKPD yang \\
pola yang & dan manfaat & bertindak selaku leading sectors pembangunan \\
memiliki & integrasi secara & sosial budaya membicarakan perbedaan- \\
keserasian fungsi. & tegas karena tidak & perbedaan nomenklatur mereka. Komponen \\
& dikomunikasikan & nilai juga tercapai yakni merujuk pada konten \\
(Johnson, Kast & dalam momentum & komunikasi dalam koordinasi tersebut, yang \\
dan Rosenweig, & tersebut. Namun & mencakup keadaan yang saling mengisi dan \\
2002: 14) & nilai (aksioma) & memberi dengan cara saling memberikan \\
& yang ditimbulkan & informasi terkait program kegiatan yang relevan \\
& oleh proses & untuk menghindarkan saling tumpang tindih \\
& koordinasi & tugas yang satu dengan tugas yang lain \\
& merekomendasikan & (konflik). \\
& prinsip integrasi. & \\
\hline
\end{tabular}

Sumber: Diolah dari data primer, 2016

Perwujudan prinsip integrasi dalam mekanisme rapat koordinasi multi stakeholders pembangunan sosial budaya Kota Makassar yang digelar oleh Bappeda tersebut berdimensi konten komunikasi. Karakteristik intrinsic prinsip integrasi inilah yang menjadi alasan mendasar timbulnya kecenderungan dimana personil yang mengikuti rapat koordinasi tidak menyadari diperankannya prinsip integrasi, yakni karena bersifat abstrak dan diwujudkan melalui pengkomunikasian konten agenda rapat. Hasil penalaran data faktual penelitian tersebut tampaknya tidak dirinci oleh Johnson, Kast dan Rosenweig (2002). Dalam konsepsinya, tidak ada penjelasan bahwa integrasi merupakan akibat yang ditimbulkan dari pelaksanaan prinsip koordinasi. Dimana koordinasilah yang dalam hal ini yang bertindak sebagai katalisator dikomunikasikannya agenda yang mengejawantah perbedaan-perbedaan nomenklatur, yang kemudian mengakibatkan selisih perspektif diantara masing-masing SKPD yang bertindak selaku leading sectors pembangunan sosial budaya Kota Makassar. Hal mana diketahui bahwa akibat perbedaan nomenklatur dan selisih perspektif SKPD itulah yang kemudian mengarahkan gagasan/ide program kegiatan masing-masing SKPD.

Dalam rapat koordinasi tersebut unsur integrasi terpenuhi mulai dengan kehadiran 8 SKPD yang bertindak selaku leading sectors pembangunan sosial budaya. Unsur integrasi berikutnya diwujudkan saat mengkomunikasikan kekhasan nomenklatur kedelapan SKPD tersebut melalui rancangan program kegiatan masing-masing. Hal ini relevan dengan penjelasan 
dalam penelitian Khatmah Ahmad (2015) bahwa proses perencanaan teknokratiki memang berlangsung dalam dua tahap; diawali dengan jaring aspirasi dalam musyawarah pembangunan dusun atau desa, kemudian dilanjutkan dengan pembahasan rancangan program kegiatan melalui institusi teknis masing-masing. Dalam momentum ini, seluruh institusi teknis (SKPD; termasuk yang bertindak selaku leding sectors pembangunan sosial budaya) mengkomunikasikan rancangan program kegiatannya pada tahap aktor teknokratik yang difasilitasi oleh bidang-bidang terkait di Bappeda.

Hal tersebut beramakna bahwa rancangan program yang dikomunikasi oleh Dinas Sosial Kota Makassar menurut perspektif nomenklaturnya dihadapan ketujuh SKPD lainnya merupakan upaya perlaksanaan prinsip integrasi. Situasi yang kemudian ditimbulkan oleh komunikasi itulah yang bernuansa pengintegrasian aspek-aspek khas dari program kegiatan masing-masing SKPD tersebut. Dengan mengacu pada orientasi pertemuan, maka dapat dipastikan, SKPD lain akan menyesuaikan rancangannya satu sama lain dan hal itu akan berlangsung secara timbal-balik. Mobilitas atau dinamika komunikasi aspek-aspek khas dari kedelapan SKPD itulah yang melahirkan integrasi. Dengan demikian, integrasi dalam hal ini merupakan nilai (value) dari proses pelaksanaan prinsip koordinasi dalam kolaborasi perencanaan tersebut.

Dikatakan komponen nilai sebab konten komunikasi koordinasi tersebut mencakup keadaan yang saling mengisi dan memberi dengan cara saling mempertukarkan informasi masing-masing SKPD yang berbeda namun dapat terkait atau dikaitkan satu sama lain melalui program kegiatan yang relevan guna menghindarkan saling tumpang tindih tugas yang satu dengan tugas yang lain. Secara linier, konten komunikasi dalam situasi tersebut sejatinya merupakan pelaksanaan amanat Permendagri Nomor 13 Tahun 2006 Tentang Pedoman Pengelolaan Keuangan Daerah dimana salah satu pasalnya mengamanatkan aturan pembiayaan program kegiatan tidak boleh diterapkan terhadap program kegiatan yang sama dan atau serupa dalam unsur-unsurnya.

Dengan bukti tersebut, perwujudan prinsip integrasi kemudian menjadi sangat jelas dan tegas kedudukannya bahwa ia merupakan komponen nilai (core value) dalam manajemen kolaborasi. Prinsip integrasi berbeda satu sama lain dengan prinsip koordinasi yang merupakan komponen inti (core component) manajemen kolaborasi. Melalui pandangan ini, peneliti menyisakan sebuah catatan kritis khusus tentang komposis unsur-unsur pembangun manajemen kolaborasi () namun bersifat hipotesis yang dapat diuji kebenarannya dalam penelitian selanjutnya.

Meski terdapat indikasi kuat kendala pengetahuan (knowledge constrain) pada diri aktor yang memerankan komunikasi prinsip-prinsip manajemen kolaborasi, namun karena komponen integrasi terpenuhi, sebagaimana temuan tersebut, maka nilai yang berorientasi pada pengendalian terhadap konflik dan penyimpangan dalam penyelenggaraan fungsi-fungsi organisasi dapat pula terpenuhi atau tercapai. Penyatuan unsur-unsur yang dalam hal ini, dimaknai mulai dari keterlibatan kedelapan wakil SKPD yang bertindak selaku leading sectors pembangunan sosial budaya Kota Makassar sampai pada konten komunikasi yang dipertukarkan, keduanya mendukung perwujudan prinsip integrasi manajemen kolaborasi . Konten komunikasi yang dipertukarkan mengarahkan secara dinamis terlegitimasinya fakta tentang keragaman nomenklatur sebagai suatu alasan untuk menyatukan unsur-unsur tersebut 
agar organisasi mampu mengoptimalkan kinerjanya meskipun berhadapan dengan pertimbangan pelik perihal amanat penganggaran program kegiatan menghadapi.

Meski secara umum, para aktor kolaborasi tidak menyadari proses pelaksanaan prinsip integrasi, namun dapat tercetuskan sikap pemenerimaan Dinas Pendidikan Kota Makassar secara faktual yakni membuka diri dan menerima transfer anak jalanan usia didik/sekolah guna mendapatkan pembinaan melalui kegiatan pendidikan masyarakatnya. Namun temuan penelitian ini disimpulkan bahwa peran positif Dinas Pendidikan terhadap kegiatan patrolii anak jalanan Dinas Sosial itu tidak serta merta dapat dikatakan bahwa program pembinaan anak jalanannya merupakan program kegiatan support terhadap program pembinaan anak jalanan Dinas Sosial. Dalilnya adalah tidak ada data faktual yang membuktikan diselenggarakannya seluruh prinsip kolaborasi pada tahap pelaksanaan kegiatan.

Argumentasi hipotetik mayor yang diperoleh melalui analisa data faktual praktek prinsip integrasi adalah sebagai berikut: "Prinsip integrasi yang terwujud dalam tahap kolaborasi perencanaan program pembangunan sosial budaya Kota Makassar merupakan komponen nilai dari pelaksanaan prinsip koordinasi manajemen kolaborasi."

Argumentasi hipotetik minor yang diperoleh melalui analisa data faktual praktek prinsip integrasi adalah sebagai berikut: "Kedudukan prinsip integrasi dalam praktek manajemen kolaborasi demikian itu tidak diwujudkan secara mandiri terpisah dari praktek prinsip lain sebab ia merupakan komponen nilai (core value).”

Tabel 3

Hasil Analisa Praktek Komunikasi yang Mengindikasikan Upaya Simplifikasi pada Pertemuan Multi Stakeholders Pembangunan Sosial Budaya Bappeda Kota Makassar

\begin{tabular}{|l|l|l|}
\hline Kondisi Ideal & \multicolumn{1}{|c|}{ Temuan } & \multicolumn{1}{c|}{ Sintesa } \\
\hline Proses & Personil peserta rapat & Proses pelaksanaan prinsip simplifikasi \\
masingana & koordinasi leading sectors & dalam manajemen kolaborasi adalah \\
institusi & pembangunan sosial Kota & substansi daripada komunikasi koordinasi \\
memaknai & Makassar mengetahui secara & delapan SKPD sebagai nomenklatur bidang \\
realitas yang & tegas perbedaan & nosial budaya yang berbeda satu sama lain. \\
melingkupinya. & institusi. Hal tersebut & Karakteristik prinsip simplifikasi terwujud \\
Dalam hal ini, & terutama menyangkut aspek- & stakeholders pembangunan sosial budaya \\
pola pikir yang & aspek mana dari suatu & Kota Makassar. \\
diterapkan & masalah sosial budaya & Perbedaan nomenklatur masing-masing \\
untuk & masyarakat yang menjadi & SKPD, bermakna akan menciptakan sudut \\
memahaminya. & fenomena sasaran program & pandang komunikasi berbeda pula. Dalam \\
& kegiatan yang dapat & konteks itulah rapat multi stakeholders \\
(Johnson, Kast & ditindaki melalui program & pembangunan sosial budaya memediasi \\
dan Rosenweig, & SKPDnya agar tidak & proses dimana prinsip simplifikasi \\
2002: 14$)$ & tumpang-tindih dengan & terwujud. \\
& upaya tindak SKPD lain. & Namun praktek prinsip ini tidak \\
& Namun pemahaman para & teridentifikasi melalui pemahaman para \\
& aktor tidak menjangkau & aktor secara utuh. Sementara prinsip ini \\
\hline
\end{tabular}




\begin{tabular}{|l|l|l|}
\hline Kondisi Ideal & \multicolumn{1}{|c|}{ Temuan } & \multicolumn{1}{c|}{ Sintesa } \\
\hline & determinasi yang menjaskan & merupakan dasar bagi pemikiran bahwa \\
& bahwa upaya & momentum komunikasi prinsip-prinsip \\
& mengkomunikasikan & kolaborasi lanjutan yang serupa pada \\
& perbedaan nomenklatur itu & tahapan pelaksanaan program kegiatan \\
& adalah proses menjalankan & \\
& prinsip simplifikasi & \\
manajemen kolaborasi. & \\
\hline
\end{tabular}

Sumber: Diolah dari data primer, 2016

Sebagaimana aras pemikiran yang digunakan dalam analisa prinsip integrasi di atas, analisa pelaksanaan prinsip simplifikasi manajemen kolaborasi menurut data faktual penelitian ini juga bergulir pada aras pemikiran yang sama. Kecenderungan data terkait pelaksanaan prinsip simplifikasi ini yang mengarahkannya pada aras pemikiran tersebut dengan penjelasan bahwa prinsip simplifikasi memiliki karakteristik dan dimensi yang sama dengan pelaksanaan prinsip integrasi. Argumentasinya berangkat dari pelaksanaan prinsip koordinasi dimana dalam proses koordinasi, agenda yang dikomunikasikan, secara spesifik mengikuti kecenderungan nomenklatur masing-masing SKPD yang sejatinya merupakan sudut pandang institusi masingmasing.

Dalam proses komunikasi koordinatif tersebut, Dinas Sosial mengetengahkan rancangan program kegiatan pembinaan anak jalanan miliknya menurut perspektif nomenklaturnya. Demikian pula halnya dengan Dinas Pendidikan Kota Makassar. Dengan mengacu pada orientasi rapat multi stakeholders pembangunan sosial budaya, maka secara teknis, pengkomunikasian rancangan program kegiatan masing-masing SKPD sebagai agenda pokok, bermakna adanya upaya mempresentasekan sudut pandang atau perspektif masing-masing SKPD. Simplifikasi sebagai upaya penyesuaian perspektif nomenklatur masing-masing SKPD, jelas terpenuhi dalam hal ini. Tataran ini kemudian yang membukakan akses bagi Dinas Pendidikan Kota Makassar (atau SKPD lain yang relevan) untuk melihat dan mengetahui adanya ruang yang beririsan (arsir) satu sama lain dengan program kegiatan pembinaan anak jalanan pada Dinas Sosial Kota Makassar.

Pada tataran itu, Dinas Sosial mempresentasekan seluruh aspek teknis rancangan program pembinaan anak jalanannya dimana salah satunya adalah kegiatan patrolii anak jalanan. Mengenai apa saja dan bagaimana teknis pelaksanaan kegiatan patroli anak jalanan. Pada saat yang sama, Dinas Pendidikan Kota Makassar akan menangkap/memahami letak keterhubungan program kegiatan pendidikan masyarakatnya dapat dilaksanakan secara saling support dengan kegiatan patroli anak jalanan Dinas Sosial. Data faktual menunjukkan bahwa apa yang berlangsung dalam pelaksanan kegiatan patroli anak jalanan Dinas Sosial Kota Makassar sejauh ini dan bagaimana Dinas Sosial Kota Makassar mesupprotnya secara estafet sesungguhnya merupakan proses alamiah yang tidak didukung pelaksanaan dan komunikasi prinsip-prinsip kolaborasi tahap pelaksanaan program kegiatan. Meski demikian, terdapat skala pencapaian tertentu yang cukup rasional. 
Dengan demikian, dapat dikatakan bahwa apabila kedua dinas tersebut melakukan penegakan dan pengkomunikasian prinsip-prinsip kolaborasi dalam rangka pelaksanaan program kegiatannya, dapat dipastikan akan diperoleh catatan skala pencapaian yang lebih baik sebagaimana motto manajemen yakni akan mencapai skala efektivitas dan efisiensi menurut rasionalitas penerapan prinsip manajemen kolaborasi dimaksud. Dengan demikian, tataran komunikasi tersebut, mengungkap dengan jelas letak peluang dan potensi dimana kolaborasi pembinaan anak jalanan Dinas Sosial dan Dinas Pendidikan dapat dipertemukan atau saling memintas satu sama lain. Hal itu juga yang meyakinkan penelitian ini bahwa apabila pelaksanaan prinsip-prinsip kolaborasi dapat diwujudkan melalui tahapan perencanaan program kegiatan, berarti akan sangat mungkin dan jelas adanya kebutuhan itu, untuk dilaksanakan pada tahapan pelaksanaan program kegiatan pembinaan anak jalanan.

Dimensi proses dimana prinsip simplifikasi terwujud menjadi legitimasi kuat adanya keinginan awal untuk membangun kolaborasi dalam operasi manajemen dalam jaringan kerja Pemerintah Kota Makassar. Terlepas dari adanya amanat Permendagri Nomor 13 Tahun 2006 tentang kewajiban seluruh jaringan kerja Pemerintah Kota Makassar melaksanakan metode penganggaran program kegiatan pembangunan daerah kota, namun indikasi ini cukup meyakinkan sebagai debut dan managerial skill untuk berkolaborasi dalam operasi manajemen Pemerintah Daerah kota Makassar. Oleh karena itu, tampak sangat mungkin perbedaan nomenklatur pada kedelapan SKPD bidang sosial budaya di Kota Makassar dapat dikomunikasikan kembali dalam konteks pelaksanaan program kegiatan. Apalagi hal itu sudah ditunjukkan melalui pelaksanaan program pembinaan anak jalanan Dinas Sosial melalui kegiatan patroli anak jalanannya yang memperoleh (secara sadar manajemen) support estafet oleh Dinas Pendidikan melalui program pendidikan masyarakatnya bagi anak jalanan usia didik/sekolah. Oleh karena itu, penelitian ini berkesimpulan bahwa melalui proses komunikasi yang mewujudkan prinsip simplifikasi, sikap pemenerimaan Dinas Pendidikan Kota Makassar menjadi terbuka dan menerima transfer anak jalanan usia didik/sekolah guna mendapatkan pembinaan melalui kegiatan pendidikan masyarakatnya. Namun temuan penelitian ini mencatatkan bahwa peran positif Dinas Pendidikan terhadap kegiatan patrolii anak jalanan Dinas Sosial Kota Makassar tersebut tidak serta merta mendudukkan kegiatan pendidikan masyarakatnya sebagai program support terhadap program pembinaan anak jalanan Dinas Sosial.

Argumentasi hipotetik mayor yang diperoleh melalui analisa data faktual praktek prinsip simplifikasi adalah sebagai berikut: "Prinsip simplifikasi yang terwujud dalam tahap kolaborasi perencanaan program pembangunan sosial budaya Kota Makassar merupakan komponen nilai dari pelaksanaan prinsip koordinasi manajemen kolaborasi." Argumentasi hipotetik minor yang diperoleh melalui analisa data faktual praktek prinsip simplifikasi adalah sebagai berikut: "Kedudukan prinsip simplifikasi dalam praktek manajemen kolaborasi demikian itu tidak diwujudkan secara mandiri terpisah dari praktek prinsip lain sebab ia merupakan komponen nilai (core value)." 
Tabel 4

Hasil Analisa Praktek Komunikasi yang Mengindikasikan Upaya Sinkronisasi pada
Pertemuan Multi Stakeholders Pembangunan Sosial Budaya Bappeda Kota Makassar
\begin{tabular}{|l|l|l|}
\hline \multicolumn{1}{|c|}{ Kondisi Ideal } & \multicolumn{1}{c|}{ Temuan } & \multicolumn{1}{c|}{ Sintesa } \\
\hline Proses & Para aktor pemeran & Pelaksanaan prinsip sinkronisasi dalam \\
menyamakan atau & komunikasi prinsip & kolaborasi pembangunan Kota Makassar \\
penyesuaian & manajemen kolaborasi & diselenggarakan hanya pada tahap \\
aspek-aspek & melaksanaan prinsip & perencanaan. \\
teknis antar & sinkronisasi sebagai upaya & Dalam momentum itu, peran komunikasi \\
institusi. Sering & teknis penyesuaian dan & para aktor cukup terarah sebagai \\
dilakukan proses & penyamaan data dan & konkurensi; dimana para aktor menyadari \\
sinkronisasi untuk & informasi program & dan memahami alokasi waktu dan aspek- \\
menyamakan & kegiatan institusi masing- & aspek teknis program kegiatan masing- \\
waktu dan data. & masing yang sejatinya & masing SKPD terorientasi pada \\
(Johnson, Kast & memiliki perbedaan khas & penggunaan bersama sumberdaya \\
dan Rosenweig, & mengikuti nomenklatur & organisasi Pemerintah Daerah Kota \\
2002: 14) & SKPD masing-masing. & Makassar yakni (Anggaran daerah). \\
\hline
\end{tabular}

Sumber: Diolah dari data primer, 2016

Upaya sinkronisasi dalam realitas faktual pertemuan multi stakeholders pembangunan sosial budaya Kota Makassar mengejawantah melalui konten komunikasi agenda yang dirapatkan. Agenda pembicaraan dalam momentum pertemuan multi stakeholders tersebut dispesifikasikan ke dalam dua topic bahasan pokok yakni agenda rancangan rencana program kegiatan SKPD bidang sosial budaya dan agenda kedua pembahasan rancangan rencana penganggaran program kegiatan SKPD bidang sosial budaya. Dengan mengacu pada pengagendaan yang sudah bersifat permanen itu, mengisyaratkan bahwa setiap tahunnya dilakukan dan dibahas kedua agenda yang sama tersebut melalui momentum pertemuan yang sama. Hal itu dilakukan dalam rangka penyusunan Rencana Kerja Pemerintah Daerah (RKPD) Tahunan. Dengan demikian, pembahasan agenda pertama menjadi akses poin dimana perwujudan prinsip sinkronisasi diturunkan. Secara utuh, perwujudan prinsip sinkronisasi itu seluruhnya diaruskan melalui proses komunikasi koordinatif.

Dinas Sosial Kota Makassar mempresentasekan rancangan program kegiatan pembinaan anak jalanannya melalui aspek-aspek teknis kegiatan, waktu dan data-data program kegiatannya. SKPD lain menyesuaikan aspek-aspek teknis program kegiatannya yang dapat relevan. Pada fase ini para aktor kolaborasi mengetahui dengan pasti bahwa agenda yang dikomunikasikan tersebut merupakan proses perwujudan prinsip sinkronisasi. Mengetahui bahwa saling mempertukarkan informasi program kegiatannya satu sama lain itu merupakan proses daripada upaya sinkronisasi.

Hal itulah yang sangat mungkin mengarahkan sikap pemenerimaan Dinas Pendidikan Kota Makassar sehingga membuka diri dan menerima transfer anak jalanan usia didik/sekolah guna mendapatkan pembinaan melalui kegiatan pendidikan masyarakatnya. Namun sangat penting untuk digarisbawahi bahwa temuan penelitian ini mencatatkan peran positif Dinas 
Pendidikan terhadap hasil pelaksanaan kegiatan patrolii anak jalanan Dinas Sosial Kota Makassar tidak serta merta mendudukkan program pembinaan anak jalanannya melalui kegiatan pendidikan masyarakat sebagai program kegiatan support terhadap program pembinaan anak jalanan Dinas Sosial.

Argumentasi hipotetik mayor yang diperoleh melalui analisa data faktual praktek prinsip sinkronisasi adalah sebagai berikut: "Prinsip sinkronisasi yang terwujud dalam tahap kolaborasi perencanaan program pembangunan sosial budaya Kota Makassar merupakan komponen nilai dari pelaksanaan prinsip koordinasi manajemen kolaborasi." Argumentasi hipotetik minor yang diperoleh melalui analisa data faktual praktek prinsip sinkronisasi adalah sebagai berikut: "Kedudukan prinsip sinkronisasi dalam praktek manajemen kolaborasi demikian itu tidak diwujudkan secara mandiri terpisah dari praktek prinsip lain sebab ia merupakan komponen nilai (core value)."

Tabel 5

Hasil Analisa Praktek Komunikasi yang Mengindikasikan Upaya Mekanisasi pada Pertemuan Multi Stakeholders Pembangunan Sosial Budaya Bappeda Kota Makassar

\begin{tabular}{|l|l|l|}
\hline \multicolumn{1}{|c|}{ Kondisi Ideal } & \multicolumn{1}{|c|}{ Temuan } & \multicolumn{1}{c|}{ Sintesa } \\
Aplikasi prinsip & Program kegiatan pembinaan & Penerapan prinsip Iptek dalam \\
ilmu dan & anak jalanan Dinas Sosial & proses persiapan dan pelaksanaan \\
teknologi dalam & menerapkan dan mengadopsi & program kegiatan pembinaan anak \\
pengelolaan, & prinsip Iptek melalui penggunaan & jalanan pada kedua dinas tersebut \\
pengendalian \& & perangkat teknologi computer. & berlangsung secara sepihak. \\
pemrosesan teknis & Komputer membantu pengelolaan & Penggunaan sarana prasarana \\
kegiatan. Tidak & data dan pemrosesannya. & berteknologi pada program kegiatan \\
terbatas pada & Teknologi komunikasi diterapkan & Dinas Sosial dan Dinas Pendidikan \\
penggunaan alat & dalam mendukung proses & tidak dilakukan sebagai pranata \\
semata, tetapi & pelaksanaan kegiatan patroli yang & teknis yang akan memudahkan dan \\
juga melibatkan & terdiri atas 4-5 tim mobile & memungkinkan dilaksanakannya \\
seluruh prinsip & menggunakan teknologi & kegiatan masing-masing secara \\
Iptek yang & transportasi kendaraan roda & kolaboratif. Meski manfaat tersebut \\
membantu dalam & empat. & terwujud secara de facto, namun \\
menjalankan & Dalam persiapan kegiatan & tidak diupayakan dan diorientasikan \\
aktivitas program. & Pendidikan Masyarakat Dinas & pada tujuan tersebut. \\
(Johnson, Kast & Pendidikan, diterapkan dan & Hal ini menunjukkan bahwa proses \\
dan Rosenweig, & diadopsi prinsip Iptek melalui & mekanisasi program kegiatan \\
2002: 14) & penggunaan computer dalam & pembinaan anak jalanan kedua \\
& pengelolaan data dan profil teknis & dinas tersebut tidak \\
program. & diselenggarakan dalam kerangka \\
& & pemahaman managerial skills. \\
\hline
\end{tabular}

Sumber: Diolah dari data primer, 2016

Serupa dengan bahasan tentang pelaksanaan prinsip koordinasi terdahulu, perwujudan prinsip mekanisasi juga tampak sebagai suatu pelaksanaan prinsip manajemen kolaborasi secara 
mandiri. Prinsip ini dapat terwujud tanpa kaitan dengan pelaksanaan prinsip manajemen kolaborasi lainnya. Sehubungan dengan hal tersebut, prinsip ini sangat niscaya faktual namun bukan merupakan output yang diarahkan sebagai proses manajerial. Hal itu dibuktikan melalui penerapan prinsip Iptek dalam proses persiapan dan pelaksanaan program kegiatan pembinaan anak jalanan pada Dinas Sosial dan Dinas Pendidikan, keduanya berlangsung secara sepihak. Penggunaan sarana prasarana berteknologi pada program kegiatan Dinas Sosial dan Dinas Pendidikan tidak dilakukan sebagai pranata teknis yang akan memudahkan dan memungkinkan dilaksanakannya kegiatan masing-masing secara kolaboratif. Meski manfaat tersebut terwujud secara de facto, namun tidak diupayakan dan diorientasikan pada tujuan tersebut. Hal ini dapat dimaknai sebagai proses mekanisasi program kegiatan pembinaan anak jalanan yang tidak diselenggarakan dalam kerangka pemahaman managerial skills. Namun fakta tersebut tidak dapat disimpulkan sebagai proses yang mendudukkan program pembinaan anak jalanan Dinas Pendidikan sebagai program support terhadap program pembinaan anak jalanan Dinas Sosial.

Secara khsusus, perwujudan prinsip mekanisasi ini pun tidak cukup membuktikan pemenuhan prasyarat tersebut. Oleh karenanya, perwujudan prinsip mekanisasi program Dinas Sosial melalui kegiatan patroli anak jalanannya dan Dinas Pendidikan melalui kegiatan pendidikan masyarakatnya, tidak dapat dikategorikan sebagai unsur pembangun fakta kolaborasi pelaksanaan kegiatan.

Argumentasi hipotetik mayor yang diperoleh melalui analisa data faktual praktek prinsip mekanisasi adalah sebagai berikut: "Prinsip mekanisasi yang terwujud dalam tahap kolaborasi perencanaan program pembangunan sosial budaya Kota Makassar merupakan komponen inti (core component) dari pelaksanaan prinsip koordinasi manajemen kolaborasi." Argumentasi hipotetik minor yang diperoleh melalui analisa data faktual praktek prinsip mekanisasi adalah sebagai berikut: "Kedudukan prinsip mekanisasi dalam praktek manajemen kolaborasi demikian itu diwujudkan secara mandiri terpisah dari praktek prinsip lain sebab ia merupakan komponen inti (core component)."

\section{SIMPULAN}

Meski belum mempraktekkannya, namun Dinas Sosial dan Dinas Pendidikan telah menunjukkan bukti faktual menjalankan prinsip-prinsip manajemen kolaborasi dalam tahapan perencanaan program pembangunan sosial budaya dalam pertemuan multi stakeholders pembangunan sosial budaya Bappeda Kota Makassar. Model proses kolaborasi pelaksanaan program tersebut merupakan derivasi pelaksanaan prinsip manajemen kolaborasi yang telah dijalankan oleh kedua instansi teknis Kota Makassar pada tahap perencanaan program. Dengan demikian, rekomendasi model proses kolaborasi pelaksanaan program tersebut membuktikan dua hal yakni; (1) Dinas Sosial dan Dinas Pendidikan (bersama SKPD bidang sosial budaya lainnya) telah dan mampu menjalankan prinsip-prinsip manajemen dalam tahapan perencanaan program pembangunan bidang sosial budaya Kota Makassar; (2) kedua SKPD tersebut dapat secara kontinyu menjalankan prinsip-prinsip manajemen kolaborasi tersebut dalam tahapan pelaksanaan programnya, termasuk program pembinaan anak jalanan Kota Makassar. 


\section{DAFTAR PUSTAKA}

Bafoutsou, Georgia and Mentzas, Gregoris. 2002. Review and FunctionalClassification of Collaborative Systems, International Journal of Information Management, Vol. 22, pp. 281-302.

Bititci, Umit S., dkk, 2004. Creating and Managing Value in Collaborative Networks, International Journal of Physical Distribution and Logistics Management. Vol.34 (3-4), p. 251-268.

Bhakoo, Vikram, 1996. Collaborative management of inventory in Australian hospital supply chains: practices and issues, Supply Chain Management, Emerald Group Publishing Limited, Vol. 17 Issues: 2, pp. 217-230

Dye, Thomas R., 1978. Understanding public policy, Prentice Hall, Inc. Englewood Cliffs.

Jafar Hosseinipour, Seyed, Hadi Rasoulzadeh, Bijan Ganji Jameshooran, Navid reza Boromand Alipour, 2013. Collaborative Perspectives in Management, International Journal of Innovative Ideas (IJII), Vol. 13 No. 2 April - June 2013.Johnson, Richard A., Kast, Fremont dan James E. Rosenzweig. 2002. Organization and Management (Organisasi \& Manajemen) Jilid 1. Terjemahan A. Hasymi Ali, Bumi Aksara, Jakarta.

Johnson, Richard A., Kast, Fremont dan James E. Rosenzweig. 2002. Organization and Management (Organisasi \& Manajemen) Jilid 1. Terjemahan A. Hasymi Ali, Bumi Aksara, Jakarta.

Kampstra R. P., and Ashayeri J., 2004. Realities of supply chain collaboration, , Emerald Group Publishing Limited, Vol. 27 Issues: 2, pp. 117-130

Kapucu, Naim, Farhod Yuldashev and Erlan Bakiev, 2009.Collaborative Public Management and Collaborative Governance: Conceptual Similarities and Differences, European Journal of Economic and Political Studies, Vol 2 (1), 2009.

Khatmah Ahmad, 2015. Kolaborasi Perencanaan di Kabupaten Mamuju. Disertasi PPS Universitas Negeri Makassar.

Mintzberg, Henry dan Quinn, James Brian, 1996. The Strategy Process: Concepts, Contexts, Cases, Prentice Hall.

McGuire, Michael, 2006. Collaborative Public Management: Assessing What We Know and How We Know It, Public Administration Review, Special Issue December 2006.

Rohrbeck, René, 2013. Collaborative Business Modelling for Systemic and Sustainability Innovations, International Journal of Technology Management, 63(1/2), pp. 4-23.

Veplun, Dirk, 2004. Partisipasi Komunitas Lokal Terhadap Pembangunan Wilayah Perbatasan Antara Republik Indonesia dan Papua New Guinea Di Propinsi Papua (RI-PNG). Penelitian. Univ. Cenderawasih, Papua.

Permendagri Nomor 13 Tahun 2006 Tentang Pedoman Pengelolaan Keuangan Daerah

Dokumen Rapat Kerja Pemerintah Kota Makassar tahun 1965

Draft Pembinaan Anak Jalanan Pemkot Makassar, 1998 